\title{
THE STATE SYSTEM AND THE STATE IDEA IN A MARGINALIZED NEIGHBOURHOOD OF COCHABAMBA, BOLIVIA.
}

\author{
EL SISTEMA-ESTADO Y LA IDEA-ESTADO EN UN BARRIO \\ MARGINALIZADO DE COCHABAMBA, BOLIVIA
}

\begin{abstract}
This paper analyses how the public policies of potable water distribution have influenced the perceptions people in Villa Chaquimayu, a marginalized neighbourhood of Cochabamba (Bolivia), have about the State. This analysis is based on the theoretical distinction between 'State-system' and 'State-idea' proposed by Abrams (1988). Following Abrams, this paper examines both the practices the Bolivian State has implemented to deliver potable water to Villa Chaquimayu (State-system), and the notions people in this neighbourhood have about the State (State-idea). By using ethnographic data, this investigation shows that a deficient public management of potable water distribution has negatively influenced people's ideas and perceptions about what is the State.
\end{abstract}

Keywords: State system, State idea, water rights, peri-urban marginality, calculated informality

\section{RESUMEN}

Este artículo analiza cómo las políticas públicas de distribución de agua potable han influenciado las percepciones que la población de Villa Chaquimayu, un barrio marginal de Cochabamba, tiene sobre el Estado. Este análisis se basa en la distinción teorética entre "Idea-Estado" y el "Sistema-Estado" propuesta por Abrams (1998). Siguiendo a Abrams, este estudio analiza tanto las practicas que el Estado Boliviano ha implementado para distribuir agua potable en Villa Chaquimayu (Sistema-Estado), y las nociones sobre el Estado que tiene la población de este barrio (Idea-Estado). A través de información etnográfica, este artículo muestra como un deficiente manejo público de la distribución de agua potable ha influido negativamente en las ideas y percepciones que la población tiene sobre lo que es el Estado.

Palabras Clave: Sistema-Estado, Idea-Estado, derechos al agua, marginalidad periurbana, informalidad calculada 


\section{INTRODUCTION}

Cochabamba is a city located in the Andes Central Mountains at an elevation of 2500 meters above sea level. Nowadays, it is the fourth largest city in Bolivia, with a population of 632,013 people (Instituto Nacional de Estadística 2012:1). One of the most distinctive characteristics of Cochabamba is the sharp difference between the predominantly wealthy neighbourhoods of the northeast zone of the city, and the poor neighbourhoods of the southern zone. Indeed, in Cochabamba's north-eastern area, most neighbourhoods have optimal infrastructure and access to basic services, whereas people in the southern zone have limited access to basic services and live in precarious conditions (Ledo 2013:10).

In Cochabamba, access to potable water has been a long-standing problem. During the early 2000's the city gained international attention as a series of protests and riots successfully stopped a governmental plan to privatize the city's water supply. Today, however, potable water distribution is still a major concern. Actually, in the southern zone of the city only $22 \%$ of people have access to the public system of potable water distribution (Marston 2015:249). In the neighbourhoods where the State does not directly provide potable water, people must find their own mechanisms to get access to this resource. This article analyses how the failure of the State to provide people with potable water in a marginalized neighbourhood (Villa Chaquimayu) influences people' imaginaries and perceptions about what is the State.

This analysis is based on the theoretical distinction between 'State-system' and 'State-idea' proposed by Abrams (1988). The latter is a notion about the State 'projected, purveyed and variously believed in different societies at different times', whereas, the State-system is a palpable nexus of 'practice and institutional structure centred in government' (Abrams 1988:58).

Following Abrams, this paper analyses both the practices the Bolivian State has implemented to deliver potable water to Villa Chaquimayu (State-system), and people's notions about the State (State-idea). The results of this study show that in Villa Chaquimayu people's negative imaginaries and understandings of what is the State are largely influenced by a series of negligent public policies.

\section{METHODOLOGY}

This research is based on a corpus of data about the actions, routines, and narratives people in Villa Chaquimayu use to get access to water. The raw data was collected through the application of a set of qualitative methods, mainly interviews, participant observation, document analysis and sma11 talks. The process of data collection was developed from mid-January to mid-April 2017 in three phases: 1) exploration phase, oriented to obtain general insights about the context of the field, 2) in-depth phase, oriented to obtain extensive data about the research questions of this investigation and, 3) wrap-up phase, where the data collected in previous phases were evaluated and validated.

The process of fieldwork was developed with two different groups of informants. First, neighbourhood's leaders (i.e. leaders of the local Water Committee and Sindicato Agrario). Second, residents of Villa Chaquimayu, in general. The perspectives of each one of these groups were fundamental to understand the bigger picture of the social dynamics in Villa Chaquimayu. The sampling strategies were different for each group. For selecting informants among neighbourhood leaders, a purposive sampling was employed, whereas a chain referral sampling was used for choosing informants among residents. 
The main objective of conducting fieldwork in Villa Chaquimayu was to collect information about the ideas, narratives, and practices people use to get access to water. The application of ethnographical-qualitative methods was the most suitable approach to collect these type of data, as these methods are 'intrinsically sensitive to the subtlety and complexity of human social life in a way that a quantitative approach cannot be' (Della Porta y Keating 2008: 300). Simply put, a qualitative approach allowed me to grasp people's perspectives, views, and narratives about a highly sensible phenomenon.

The information was analysed using Qualitative Data Analysis Software (Atlas.ti) and coded using a combination of open and thematic codes. According to Boyatzis (1998), a thematic code is a pattern found in the information, which can be 'generated inductively from the raw information or generated deductively from theory or prior research' (Boyatzis 1998:7).

The thematic codes used in this investigation were based both on the categories found in the raw data collected and in categories present in the theoretical framework. The main reason for employing this coding strategy is that it allowed me to include codes and themes based both on theoretical concepts and in raw data. In order to preserve my informants' confidentiality, all names cited in this article are pseudonyms.

\section{RESULTS}

\section{Villa Chaquimayu: Between illegality and marginality}

Villa Chaquimayu is a neighbourhood located in the 'District 9' of the south zone of Cochabamba. The inhabitants of Villa Chaquimayu have different origins and cultural backgrounds, nevertheless, they share quite a few general characteristics in terms of traditions and language. For instance, people in Villa Chaquimayu are bilingual, speaking both Quechua and Spanish in their everyday life, traditional Bolivian rituals, such as the 'challa', are commonly practised especially during carnival time, and autochthonous Bolivian clothing is widely used in daily life by females (men usually use more westernised clothing).

Villa Chaquimayu has serious problems in infrastructure, sanity, living conditions and access to basic resources. For instance, schools and medical centres in the zone are not enough to suffice the requirements of the population, there are high levels of pollution, the public system of potable water distribution is not present in the neighbourhood, and its inhabitants do not have legal property rights over their houses or land. Most houses in Villa Chaquimayu are in poor material conditions.

Nevertheless, there are also a few houses in very good conditions. These houses are commonly known as 'Eurocasas' (euro-houses), as many of them were built using remittances. Most roads in Villa Chaquimayu are dirt and steep streets, which are in poor conditions. Nevertheless, the main street of the neighbourhood, Avenida Panamericana, is currently being asphalted. This street plays an important role in the dynamics of the neighbourhood, as several small-scale stores are placed there, including pharmacies, restaurants, grocery stores, a medical centre, schools and hardware stores.

Neighbourhood dynamics in Villa Chaquimayu are highly influenced by processes of internal and international migration. In Bolivia, the phenomenon of internal migration is closely related to the neoliberal policies implemented by the government from 1985 to mid-2000's. These reforms included a relocation of many miners and workers from the rural areas of the country to the three main Bolivian cities: Santa Cruz, La Paz and Cochabamba (Vacaflores 2003:2-5). Indeed, during the last 30 years, Villa Chaquimayu has received an important number of migrants coming from regions such as Chapare, Oruro, Potosí or La Paz. This influx of migrants caused a very rapid and aggressive process 
of urbanisation in the neighbourhood, mainly promoted by a series of loteadores (land traffickers) who sell land and houses without title deeds or legal property rights (Torrico y Walnycki 2015:98).

On the other hand, international migration also plays an important role inside Villa Chaquimayu, as many people from this neighbourhood have migrated to other countries, especially Argentina, Chile, Brazil, Spain, and Italy. The processes of international migration in Bolivia are mainly associated with the fragility of the Bolivian economy and the labour-force requirements of countries with more developed economies (Vacaflores 2003:2-5). In Villa Chaquimayu, the people who have migrated overseas usually send remittances to their families in Bolivia, improving their economic situation.

The internal organisation of Villa Chaquimayu is based on two grassroots institutions. The first one is a Sindicato Agrario (Agrarian Syndicate). This institution manages issues related to infrastructure, security, internal organisation, and conflicts. The second institution is a Comité de Agua (Water Committee). This organisation is specifically oriented to cope with the lack of potable water in the zone. Put it another way, the existence of this institution is directly associated with the absence of the State and private companies in potable distribution. In words of a leader of the Water Committee, 'I believe that people's necessities are what forced us to create an organisation to find solutions to these problems' (A. López, personal communication, February 20, 2017). Nowadays, Villa Chaquimayu's Water Committee uses a communal water well to provide potable water to 140 households. The residents of the neighbourhood require a membership in order to become members of the Water Committee. The price of this membership is roughly 1000 dollars (this is approximately the equivalent to the costs people paid to build a water well in the zone).

\section{A State-System marked by illegality}

A key element to understanding the policies the State applies in Villa Chaquimayu is the fact that the neighbourhood is considered as an 'illegal settlement' (asentamiento ilegal). This section explains the meaning of 'illegality' in the Bolivian context and analyses how illegality influences the policies implemented by the State in Villa Chaquimayu in order to characterize the State-system.

In Bolivia, illegal settlements are neighbourhoods in which people do not have legal 'property rights' (derecho propietario) over their houses or land. In Cochabamba, several illegal neighbourhoods have been created throughout the city because many people -mainly loteadores (land traffickers)- have been illegally occupying and selling wasted and unused land to satisfy the increasing housing demands of poor people.

The main reason why some neighbourhoods do not have 'property rights', therefore, is because of the high levels of informality that characterise Cochabamba's urban expansion. In the case of Villa Chaquimayu, this neighbourhood used to be an agrarian zone. Nevertheless, a process of urbanization started in this zone when loteadores began to sell land and houses to internal migrants. Most people in Villa Chaquimayu have made important economic investments to buy their houses, consequently, the label of 'illegality' associated with the neighbourhood is not well received among most residents of the neighbourhood. In words of a water committee leader:

When they [the government] tell
us that we are illegals, it looks
like if we would have done some-
thing extremely bad. For them, it
is like if we have built our hou-
ses in a random place, overwhel-
ming everything on our way. That
is not what happened here, we are
not illegals (M. Pérez, personal
communication, March 23, 2017).

At first, the existence of illegal settlements goes against the law and the interest of the 
State (Walnycki 2015:15). Therefore, the lack of property rights implies that people in Villa Chaquimayu must deal with long bureaucratic processes and with a lack of funding and support from the State. In this context, dealing with State institutions is usually a frustrating task for neighbourhood leaders. Mr. Estevez -a former communal leader- illustrated this point in the following anecdote:

What they [government officials] always tell us when we have a claim is: 'property rights'. That is the big excuse they always have, to say that we are illegal settlements $[\ldots]$. A few years ago, we planned to build a coliseo [a sports centre]. I had that idea because we don't have that type of spaces for recreation in the neighbourhood. I talked with several people in the government. They told me that we needed to have property rights and, that as soon as when we get property rights they would help us. It's frustrating because meanwhile we are in the long process to try to get our property rights, they will forget all the promises they made (J. Estevez, personal communication, February 13, 2007).

During 2017, the community leaders of Villa Chaquimayu have been working for obtaining property rights and, thus, legalise the neighbourhood. This, however, has not been an easy or straightforward process. Indeed, community leaders have faced several bureaucratic obstacles. For instance, in early 2017, the legalisation process of the neighbourhood was in a standby phase for several weeks, because the official responsible for the process decided to take a long and unscheduled period of vacation.

We are doing the paperwork needed to obtain our property rights. The worst thing about that, is that the architect who is in charge $[. .$.$] decided to take vacations,$ and he didn't inform that to us. All the plans we have are stuck $[\ldots]$. The only thing we can do is wait until he comes back. There you can have an idea of how our politics work (M. Pérez, personal communication, March 23,2017).

The neighbourhood's illegal status currently does not cause major problems to the local Water Committee. Indeed, despite the fact that this neighbourhood is considered as an illegal settlement, its Water Committee has been regularised and operates legally since 2010. In other words, people in Villa Chaquimayu do not have property rights, but they can legally organise a Water Committee to get access to potable water.

\section{Potable water, informality and the State} In Villa Chaquimayu, the State has never directly taken the responsibility for providing potable water to its citizens. Indeed, Semapa (Cochabamba's public water utility) does not operate in this neighbourhood. Nevertheless, the State has indirectly facilitated the work of Villa Chaquimayu's Water Committee through two different mechanisms. First, the State recognises the Water Committee as a 'legal institution', which facilitates the participation of this institution in bureaucratic processes. Second, the State has indirectly supported some of the committee's projects for providing potable water to the zone. For instance, during the 1990s, the Bolivian government, through the Environment Ministry (Ministerio de Ambiente), provided alimentation to the inhabitants of Villa Chaquimayu who worked as volunteers for building water-access infrastructure. In words of Mr. López, who worked as a volunteer in this project:

In 1992, people organised a communal work for getting access to water from a nearby creek. This project, I believe, was done with the collaboration of Environment [Ministry]. They collaborated just with the alimentation. People who worked as volunteers received alimentation. They worked every week with the food they received as collaboration, but they never received any money (A. López, personal communication, February 20, 2017). 
This approach -in which the State allows informal institutions to flourish in order to fill the absence of formal basic services- has been denominated as 'calculated informality' (Walnycki 2015:9). The Bolivian Constitution has officialised Water Committees' calculated informality, as it determinates that the State can rely on communal institutions, such as Water Committees, to provide potable water to its citizens. In Villa Chaquimayu, the calculated informality created by the State has serious inconveniences.

First, Villa Chaquimayu's Water Committee does not have the technical and financial capacities to suffice the demands of the population in terms of quality and quantity of water. The absence of the State in potable water distribution, therefore, has negative consequences for people's living conditions (Ledo 2013:5). Second, the fares people pay for Water Committee's services are higher than the fares charged by Cochabamba's public water utility in wealthier neighbourhoods.

Subsequently, the model in which communal institutions replace public utilities aggravates the inequalities and the spatial segregation existent within the city, as people in the poorer neighbourhoods pay more for water than people in the wealthier zones. Third, Villa Chaquimayu's Water Committee does not provide potable water to the whole neighbourhood.

Actually, most people in Villa Chaquimayu still relies on aguateros (informal water trucks) to get access to water. The services aguateros provide are more expensive and have less quality in comparison the Water Committee or Semapa's services. The State's policies in Villa Chaquimayu completely neglect to people who do not participate in the Water Committee.

Overall, the model in which the State transfers its responsibility into self-funded water committees has direct consequences over people's living conditions, and deepen the differences existent between people who live in the wealthier and in the marginalised areas of the city. One of the possible macro-level solutions the State has for improving the access to water of people living in the marginalised areas of Cochabamba is the 'Misicuni project'. Misicuni is a dam oriented to provide potable water to Cochabamba by diverting water from a nearby river.

The Misicuni project started in 1987 and was inaugurated in 2017 (the project presented serious technical failures just a few days after being inaugurated). Considering that in Villa Chaquimayu, the neighbourhood's system of pipes is not connected to Cochabamba's main water network, the Misicuni dam cannot provide water to the neighbourhood yet. In any case, the Misicuni project could rapidly change the dynamics and the way in which people get access to water in this neighbourhood.

The next section analyses the narratives the majority of my informants have about what is the State (i.e. their State-idea). For analytical purposes, these narratives have been classified in three clusters: First, narratives about the absence of the State. Second, narratives about the role of the State in Cochabamba's spatial segregation. Third, narratives about the differences between the State and communal institutions.

\section{Narratives about the State: the absence of the State}

The direct absence of the State in basic services provision influences the way people in Villa Chaquimayu understand what is the State. Many people in this neighbourhood are aware that access to basic services is their constitutional right, and that the State is primarily responsible for providing people with access to these services. Nonetheless, for them, the 'real' State is not an institution oriented to protect people's rights. On the contrary, people associate the State with negative connotations like extensive bureaucracy, corruption or the pursuit of personal interests. The following quotes illustrate this point: 
We know that the Constitution says that the State has the obligation of promoting policies oriented to provide people with health, education and basic services, but here we don't have any of that $[. .$.$] The constitu-$ tion says, everybody has the right of having a place to live. But the authorities, they simply don't understand that. Imagine this: I have lived here since 1991. I have been living in this house for 26 years. In all these 26 years, we haven't been able to legalize the neighbourhood [...] It's too much time. Too much time without basic services [...] The constitution says, 'we all have equal rights', but in reality, not everybody has access to health or education (M. Pérez, personal communication, March 23, 2017). [In the State] everything is based on personal calculations and corruption. Let's say, for instance, that the municipality has a project. Then, the municipality asks the government for support, but, the government then says that they haven't received any project, so they will blame the municipality for their lack of initiatives. We don't know to whom we should trust. These things happened, and the only ones who are affected are the inhabitants of the zone (R. Aguirre, personal communication, February 22, 2017).

As these quotes illustrate, people in Villa Chaquimayu often understand what the State is in pragmatic terms. In other words, for these people, the State is not necessarily what the constitution or the textbooks say it is. On the contrary, the State is reflected in the palpable actions it takes in the neighbourhood. Take for example this quote:

Here the State has the obligation to provide water, but look how it works... Perhaps the government does not have the information; perhaps they do not know that we do not have [water]. There is too much bureaucracy, too much paperwork. We rather organise that by ourselves, if we don't we waste years. If we wait for the government to drill a well it might take more than two years. In addition, I do not even have expectations about the municipality (A. López, personal communication, March 12, 2017).

On the other hand, Villa Chaquimayu's Water Committee is seen as a more pragmatic institution in comparison to the State, as the Water Committee has the sole purpose of providing people with access to one of the resources that the State does not provide. In other words, Water Committees fill the gaps left by the State. Take for example these quotes taken from an interview with one of the Water Committee's leaders:

We are not the only ones with a water well. Everybody in this zone has wells. If you go to other places, people will tell you exactly the same: they do it with their own resources. That is the only way. Neither the municipality nor the governorate do anything (A. López, personal communication, February 20, 2017).

\section{Narratives about the State: Cochabam- ba's spatial segregation}

The unequal infrastructure and funding existent between the different zones of Cochabamba also plays an important role in the narratives people build about what the State is. Indeed, many people consider that the State intentionally neglects the (poor) southern zone of the city and privileges the (wealthier) northern zone. The following quote illustrates this perspective:

What really pisses me off is that thirty years ago, the streets in the north were just like the streets are here. But now they have everything, all the basic services. They live in good conditions. Whereas, here, we do not have anything. It seems to me that there is a huge discrimination. It is like people living in the southern zone were inferiors. In the south, everything works slowly, but on the other side [the north] they accelerate everything [...] (M. Pérez, personal communication, March 23, 2017). 
As it can be seen, for Mr. Pérez the State accomplishes an efficient work in the northern zone, but this is not the case in the southern zone. In other words, for him, the State is not a pro-poor institution. Indeed, Mr. Pérez, and several other informants, associated the State with ideas of discrimination; this is to say that for them, the State is an institution that discriminates poor people. Take for example this quote taken from an interview with Doña G. Morales:

Basically, the southern zone has always been neglected, it has been discriminated. As people say, people in the south must stand by themselves [como quien dice, la gente del sud que se la aguante]. But, I can see that this is not always the case in the north, it's different (G. Morales, personal communication, February 2, 2017).

All in all, people often attribute the spatial segregation existent in Cochabamba, to the actions and practices the State implements.

6. Narratives about the State: the contrast between the State and communal institutions For the residents of this neighbourhood, politics usually have two different connotations: one associated with the work of the State and the other associated with the work of communal institutions (e.g. Water Committee). The following quotes - collected in a series of interviews with inhabitants of Villa Chaquimayu and leaders of the Water Committee- illustrate the views people have about the practices of communal and State institutions:

We [the water committee] work with our own effort. We work as volunteers; we buy the infrastructure and materials with our own money. If we go to the authorities -to the governorate or the municipality- we do not get anything, I do not know why, but they do not help us (A. López, personal communication, February 20, 2017). This is how politics work; Bolivian politics are not efficient. Everybody does what they want, and everything is a mess. People are waiting to solve the necessities, whilst, others -the politicians- don't care. We are used to it, at least in this zone (M. Pérez, personal communication, March 23, 2017). Here, we [the people of Villa Chaquimayu] had to drill a well by ourselves, with our own money, with our own sacrifice. No institution helped us. We did it with our own sacrifice. It cost us almost 60,000 dollars, and no one was here to help us (J. Estevez, personal communication, February 13, 2017).

As it can be seen, the work of the Water Committee is usually associated with notions such as self-sacrifice or communal work, whereas the practices of the State are associated with notions such as corruption, ineffectiveness or chaos. In other words, there is a dichotomy by which the work of the State has negative connotations, whereas the work of the Water Committee is associated with more positive ideas.

It is also interesting to note that, for people in Villa Chaquimayu, the field of action of the Water Committee is discursively associated to the everyday necessities people have. In other words, the actions taken by the water committee have a palpable outcome inside the neighbourhood, whereas the State's policies have been less tangible. In this sense, communal institutions are usually perceived to be closer to the people than macro-level politics. Mr. Luna, another communal leader in Villa Chaquimayu, exemplified this point in the following way:

There is too much discrimination from the government. I ask myself: many people live in this zone and yet we do not have recreational spaces, a hospital, or a good school [...] They don't give resources to people who must need it. Inside the neighbourhood, we have to think by ourselves how we can progress, we must take actions and decisions by ourselves, and we cannot wait (M. Luna, personal communication, February 6, 2017). 
In this context, people in Villa Chaquimayu feel more connected with neighbourhood institutions such as the Water Committee than with the State or macro-level politics.

\section{CONCLUSION}

Following Abrams (1998), this paper analysed the relation between the State's policies and practices (State-system), and the narratives people build about what is the State (State-idea). The analysis of the public management of potable water distribution in Villa Chaquimayu shows that negligent public policies have a negative impact on people's imaginaries and understandings of what is the State. In other words, people's ideas about the State are not only based on the concepts transmitted by schools and media, but also on people' everyday experiences.

First, in Villa Chaquimayu the practices and policies implemented by the State (i.e. the State-system (Abrams 1988)) are highly influenced by a series of bureaucratic obstacles created by the 'illegal' status of the neighbourhood. In other words, against the backdrop of illegality, the State does not address many of the neighbourhood's needs. Nevertheless, the State's policies in relation to potable water distribution are based on a 'calculated informality' (Walnycki 2015:9) in which the State intentionally transfers to local institutions its responsibility of providing people with access to potable water.

In other words, the State does not directly provide people with access to water, but it allows informal and communal institutions to flourish in order to fill the absence of basic services. Indeed, in Villa Chaquimayu, the State has legalised and indirectly supported the actions of the local Water Committee. For instance, throughout its history, the Water Committee has built infrastructure projects based on people's voluntary work. The State has not directly funded these projects, but it has provided food to volunteers during their working days. In this regard, Davis (1999) has noted that some groups of citizens are more distanced from the state than others, and it is the extent of citizens' distance from the State that explains their likelihood of joining social movements and the strategies they are likely to pursue (Davis 1999:601). Indeed, in Villa Chaquimayu, the systematic practices of exclusion implemented by the State are closely related with the everyday political practices people in Villa Chaquimayu use to get access to potable water.

Second, the policies implemented by the State in Villa Chaquimayu have a direct influence on people's ideas and narratives about what is the State i.e. their State-idea (Abrams 1988:58). Simply put, people's notions about the State usually match with the palpable actions the State implements in the neighbourhood. In general terms, most of my informants consider that in illegal neighbourhoods such as Villa Chaquimayu, the State is an ineffective and unfair institution, as people associate the State with ideas such as abandonment and spatial segregation. In contrast, the neighbourhood's Water Committee is best regarded among the inhabitants of the zone, as this institution directly deals with the problems caused by the State's absence. To sum up, the neighbourhood's illegality and the calculated informality implemented by the State are directly associated with a series of negative imaginaries about what is the State. The State cannot be a fully-legitimised institution in neighbourhoods such as Villa Chaquimayu, as long as it does no address peoples' basic needs, such as the access to potable water. 


\section{REFERENCES}

Abrams, P. (1988). Notes on the Difficulty of Studying the State (1977). Journal of historical sociology, 1 (1), 58-89.

Boyatzis, R. E. (1998). Transforming Qualitative Information: Thematic Analysis and Code Development. London, England: SAGE Publications.

Davis, D. (1999). The power of distance: re-theorizing social movements in Latin America. Theory and Society, 28 (4), 585-638.

Della Porta, D., Keating, M. (2008). Approaches and methodologies in the social sciences: A pluralist perspective. New York, United States of America: Cambridge University Press.

Instituto Nacional de Estadística (2012). Resúmen Censo de Poblacion y Vivienda. Retrieved from http://censosbolivia.ine.gob.bo/censofichacomunidad/c_listadof/listar_comunidades

Ledo, C. (2013). El Agua Nuestra de Cada Día. Retos e iniciativas de una Cochabamba incluyente y solidaria. Cochabamba, Bolivia: CEPLAG-UMSS.

Marston, A. J. (2015). Autonomy in a post-neoliberal era: Community water governance in Cochabamba, Bolivia. Geoforum, 64 (1), 246-256.

Torrico, M. E., Walnycki, A. (2015). ¿Las Chompas en el poder? El mito de la participación en los barrios pobres de Cochabamba, Bolivia. Medio Ambiente y Urbanización, 82 (1), 81-116.

Vacaflores, V. (2003). Migración interna e intraregional en Bolivia: Una de las caras del neoliberalismo. Aportes Andinos, 7 (1), 1-8.

Walnycki, A. (2015). Rights on the edge of the city: the right to water and the peri-urban water committees of Cochabamba. Retrieved from http:// pubs.iied.org/pdfs/10758IIED.pdf

\section{INTERVIEWS}

Aguirre, R. Interview with the author, February 22,2017. Estevez, J. Interview with the author, February 13, 2007. López, A. Interview with the author, February 20, 2017. López, A. Interview with the author, March 12, 2017. Luna, M. Interview with the author, February 6, 2017. Morales, G. Interview with the author, February 2, 2017. Pérez, M. Interview with the author, March 23, 2017.

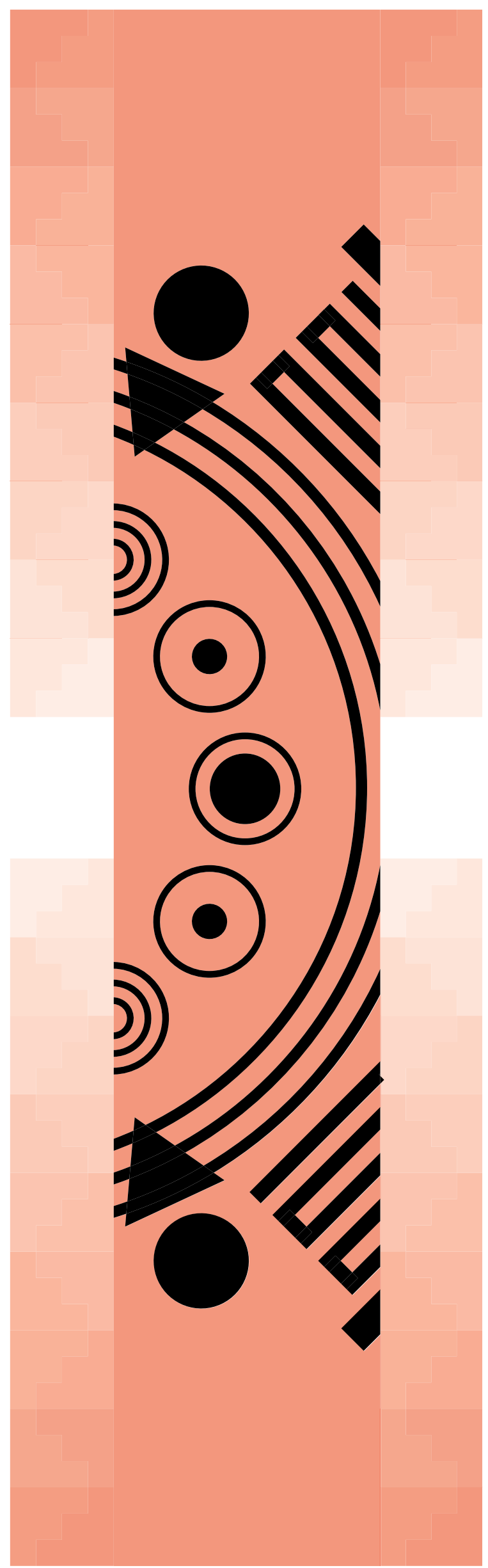

